\section{Journal of Biomedical and Pharmaceutical Research}

Available Online at www.jbpr.in CODEN: - JBPRAU (Source: - American Chemical Society) PubMed (National Library of Medicine): ID: (101671502)

Index Copernicus Value 2017: 92.04

Review Article

Volume 8, Issue 1: January-February: 2019, 55-70
ISSN (Online): 2279-0594

ISSN (Print): 2589-8752

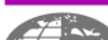

\title{
A REVIEW ON APPLICATIONS OF PROBIOTICS IN HUMAN HEALTH AND DISEASE
}

\section{Yasaman Pakdaman}

Pharm. D, Krupanidhi College of Pharmacy, Chikkabellandur, Carmelaram Post, Varthur Hobli, Bangalore-560035.

Article Info: Received 02 January 2019; Accepted 20 February. 2019

Cite this article as: Pakdaman, Y. (2019). A REVIEW ON APPLICATIONS OF PROBIOTICS IN HUMAN HEALTH AND DISEASE. Journal of Biomedical and Pharmaceutical Research, 8(1).

DOI: https://doi.org/10.32553/jbpr.v8i1.578

Address for Correspondence: Yasaman Pakdaman, Pharm. D, Krupanidhi College of Pharmacy, Chikkabellandur, Carmelaram Post, Varthur Hobli, Bangalore

Conflict of interest statement: No conflict of interest

\section{ABSTRACT:}

The emergence of resistance and tolerance to the existing drugs has created a decreased efficacy of these drugs in use. Along with the advancement in other fields of medicine, the problem of resistance has been tried to be overcome by increasing the drug delivery to the target site by the use of polymers or through nanotechnology, synthesis of new drugs, either by the use of proteomics or synthesis from lactic acid bacteria, or marine microorganisms. Recent research has revealed a potential therapeutic role for the manipulation of the microbiota in the maintenance of human health and treatment of various mucosal disorders. Probiotic microorganisms can shape the immune system both at the local and systemic level which will allow future probiotics as treatments for many diseases. The benefits include either a shortened duration of infections or decreased susceptibility to pathogens.

Probiotic bacteria have multiple and various influences onthe host. Different organisms can influence the intestinal luminal environment, epithelial and mucosal barrier function, and the mucosal immune system. The numerous cell types affected by probiotics involve epithelial cells, dendritic cells, monocytes/macrophages, $B$ cells, $T$ cells. Probiotics do not always colonize the intestinal tract to exert their effects. Some probiotics like Bifidobacterium longum become part of the human intestinal microflora, whereas others like Lactobacillus casei indirectly exert their effects in a transient manner as they pass through by remodeling or influencing the existing microbial community.

Probiotics seem to have promising role in shortening duration of infections or decreasing susceptibility to the pathogens. Incorporation of probiotics in nutrition as a means of derivation of health benefits. The best documented effects include bowel disorders such as lactose intolerance, antibiotic-associated diarrhea and infectious diarrhea, emerging evidence accumulates concerning their potential role in various other conditions. In the same time as relevant consumer awareness grows, such products are becoming increasingly popular and tend to represent one of the largest functional food markets.

Key words: probiotics, Antibiotic associated diarrhea, microorganisms, Antibiotic resistance, Lactic acid bacteria. 


\section{INTRODUCTION}

The emergence of resistance and tolerance to the existing drugs has created a decreased efficacy of these drugs in use. Along with the advancement in other fields of medicine [1, 2, 3], the problem of resistance has been tried to be overcome by increasing the drug delivery to the target site by the use of polymers $[4,5]$ or through nanotechnology [6,7], synthesis of new drugs, either by the use of proteomics $[8,9,10]$, or synthesis from lactic acid bacteria [11], or marine microorganisms [12]. However, now a days, the trend is being changed from synthetic drugs to the natural drugs either from plants or microbes to control the diseases. The natural products are constantly being screened for their possible pharmacological value particularly for their anti-inflammatory [13], hypotensive [14], hepatoprotective $[15,16]$, hypoglycemic $[17,18]$, amoebicidal [19], as flatulence or diarrhea most probably by their effect on the gut microflora [20,21,22], anti-fertility, control the infections acting as antibiotic [23], spasmolytic, bronchodilator [24], antioxidant [25], suppress tumors and protect against colon/bladder cancer [26] and antiParkinsonism properties. As a natural product, probiotics have been emerged as new management tools for the control of different diseases.

Recent research has revealed a potential therapeutic role for the manipulation of the microbiota in the maintenance of human health and treatment of various mucosal disorders. Probiotic microorganisms can shape the immune system both at the local and systemic level which will allow future probiotics as treatments for many diseases. The benefits include either a shortened duration of infections or decreased susceptibility to pathogens [27].

The term probiotic was derived from the Greek, meaning "for life." The Food and Agriculture Organization of the United Nations
(FAO) and the World Health Organization (WHO) have stated that there is adequate scientific evidence to indicate that there is potential for probiotic foods to provide health benefits and that specific strains are safe for human use. The use of probiotics is not a new invention but in fact it exists in our traditional food such as preparation of Dahi, Yoghurt, Koumis, and Leben, different types of cheese, beverages and alcoholic products [28]. An expert panel commissioned by FAO and WHO defined probiotics as "Live microorganisms which when administered in adequate amounts confer a health benefit on the host." [29].

The development of adjuvant or alternative therapies based on bacterial replacement is becoming important owing to the rapid emergence of antibiotic-resistant pathogenic strains and the adverse consequences of antibiotic therapies on the protective flora, which enhances the risk of infection [30].Probiotics were originally used to improve the health of both animals and humans through the modulation of the intestinal microbiota. At present, several wellcharacterized strains of Lactobacilli and Bifidobacteria are available for human use to reduce the risk of gastrointestinal (GI) infections or treat such infections [31]. Some of the beneficial effects of probiotic consumption include improvement of intestinal health by the regulation of microbiota, and stimulation and development of the immune system, synthesizing and enhancing the bioavailability of nutrients, reducing symptoms of lactose intolerance, and reducing the risk of certain other diseases [32].

\section{MECHANISMS OF PROBIOTIC FUNCTION:}

Probiotic bacteria have multiple and various influences onthe host. Different organisms can influence the intestinal luminal environment, epithelial and mucosal barrier function, and the mucosal immune system. The numerous cell types affected by probiotics involve 
Yasaman Pakdaman, Journal of Biomedical and Pharmaceutical Research

epithelial cells, dendritic cells, monocytes/macrophages, B cells, T cells. [33]. Probiotics do not always colonize the intestinal tract to exert their effects. For example, some probiotics like Bifidobacterium longum become part of the human intestinal microflora, whereas others like Lactobacillus casei indirectly exert their effects in a transient manner as they pass through by remodeling or influencing the existing microbial community [34].

The following are the major mechanisms of action of probiotics on the host,

\section{Barrier function:}

By decreasing apoptosis of intestinal cells or by increased mucin production, probiotics are capable of influencing many of the components of epithelial barrier function. Lactobacillus rhamnosus GG was able to prevent cytokine-induced apoptosis in intestinal epithelial cell models by inhibiting tumor necrosis factor (TNF) [35]. Lactobacillus species have been shown to increase mucin expression in vitro in human intestinal epithelial cells, thus blocking pathogenic $E$. coli invasion and adherence [36, 37]. Lactobacillus rhamnosus GG has shown to prevent inflammation and programmed cell death of the lining intestinal epithelial cells [38] and shown to exert mitogenic effects and enhancing mucosal regeneration [39].

\section{Production of antimicrobial substances:}

Probiotics either by inducing host cells to produce peptides or by directly releasing peptides interfere with pathogens, and prevent epithelial invasion. Defensins (hBD protein) and cathelicidins are the antimicrobial peptides expressed constitutively by the intestinal epithelial cells and display antimicrobial activity against a wide variety of bacteria, fungi and some viruses [40]. Healthy volunteers who received probiotics had increased fecal hBD protein and remained elevated for 9 weeks after completion of 3 weeks of probiotic treatment [41, 42]. Probiotics have been shown to suppress pathogen growth through the release of a variety of antimicrobial factors like defensins, bacteriocins (Bacillus clausii constitute $<1 \%$ of gut microbial communities, stimulate CD4 proliferation, and produce bacteriocins to limit the growth of potential pathogens [43], hydrogen peroxide, nitric oxide, and short chain fatty acids (SCFA), such as lactic and acetic acids, which reduce the $\mathrm{pH}$ of the lumen [44]. SCFA can disrupt the outer membranes of gram-negative pathogens causing inhibition of pathogen growth [45]. Bacteriocins can either permeabilize the inner membrane of gramnegative bacteria, leading to disruption and formation of pores [46]. Microcins (produced by gram negative bacteria), on the other hand, can influence the inner membrane, enzymes that are involved in DNA or RNA structure and synthesis, or enzymes which are essential for protein synthesis [47].

\section{Competition for adherence:}

Probiotic bacteria compete with invading pathogens for binding sites to epithelial cells and the overlying mucus layer in a strainspecific manner. Surface layer proteins purified from $L$. helveticus R0052 inhibited enterohemorrhagic Escherichia coli 0157:H7 adherence and the subsequent rise in permeability, without modifying the growth of the pathogen [48]. S. boulardii secretes a heatunstable factor which has shown to be responsible for the decreased bacterial adherence [49].

\section{Immune modulation:}

L. casei have been shown to supplement total and pathogen-specific secretory IgA levels upon infection in mice by stimulating $B$ cell class switching to IgA [50]. Specific antibodies against $L$. casei were not produced, indicating the non-responsiveness of the gut immune system to this beneficial bacterium. In infant rabbits pretreated with $L$. casei, morbidity of 
subsequent EHEC (Entero-Hemorrhagic E. coli) infection was reduced due to increased mucosal levels of anti-EHEC and anti-Shiga toxin IgA antibodies compared with controls [51]. L. casei down-regulated the transcription of a number of genes encoding proinflammatory effectors such as cytokines and chemokines and adherence molecules induced by invasive $S$. flexneri. This resulted in an antiinflammatory effect that appeared mediated by the inhibition of the NF-KB pathway, particularly through stabilization of I-KB $\alpha$ [52].

\section{Interference with quorum sensing signaling:}

Bacteria communicate with each other as well as with their surrounding environment through chemical signalling molecules called autoinducers. This phenomenon is called quorum sensing [53]. The use of this cell-to-cell signaling mechanism facilitates the regulation of important traits of enteric microbes that allow them to successfully colonize and/or start infection in their host [54]. Medellin-Pena et al. [55] demonstrated that Lactobacillus acidophilus secretes a molecule that inhibits the quorum sensing signalling or directly interact with bacterial transcription of $E$. coli 0157 gene, involved in colonization and thus, bacterial toxicity is opposed.

\section{APPLICATIONS OF PROBIOTICS IN HUMAN HEALTH:}

Probiotic research suggests a range of potential health benefits to the host organism. The potential effects can only be attributed to tested strains but not to the whole group of probiotics. Probiotics have shown to provide a diverse variety of health benefits to human, animal, and plans. However, viability of the microorganisms throughout the processing and storage play an important role in transferring the claimed health effects. Therefore, the health benefits must be documented with the specific strain and specific dosage [56]. Microbial communities also enhance nutritive value by producing several enzymes for the fermentation of nondigestible dietary residue and endogenously secreted mucus [57] and help in recovering lost energy in the form of shortchain fatty acids. They also have a role in the synthesis of vitamins [58] and in the absorption of calcium, magnesium, and iron [59].

\section{Infection control:}

Probiotics are involved in altering gut $\mathrm{pH}$, antagonizing pathogens through the production of antimicrobial compounds, competing for pathogen binding and receptor sites as well as for available nutrients and growth factors, stimulating immunomodulatory cells, and producing lactase. The most important point of Probiotics is that they are proven to be safe, cost effective, and could interfere with the microbial infection. In 1994, the World Health Organization deemed Probiotics to be the next-most important immune defense system when commonly prescribed antibiotics are rendered useless by antibiotic resistance [60].

\section{Cholesterol reducing ability:}

There have been several mechanisms proposed for the purported cholesterol lowering effects of probiotics, including deconjugation of bile acids by bile-salt hydrolase enzymes of probiotics [61], assimilation of cholesterol by probiotics [62], co-precipitation of cholesterol with deconjugated bile [63], cholesterol binding to cell walls of probiotics [64], incorporation of cholesterol into the cellular membranes of probiotics during growth [65], conversion of cholesterol into coprostanol [66] and production of short-chain fatty acids upon fermentation by probiotics in the presence of prebiotics [67]. A study aimed to investigate whether the combination of plant sterol esters with soy protein or soy isoflavones would have extra cholesterol-lowering effects. In conclusion, the combination of PSE and soy 
Yasaman Pakdaman, Journal of Biomedical and Pharmaceutical Research

protein more dramatically lowers plasma lipids than the individual ingredients [68].

\section{Lactose intolerance:}

In persons lacking lactase, when lactose reaches the large intestine, it is metabolized by the colonic microflora to produce methane, carbon dioxide, and hydrogen and altering the osmotic balance in the colonic lumen, causing symptoms such as cramping, diarrhea, flatulence, and abdominal bloating [69]. A number of human studies have shown that high-lactose milk products supplemented with starter cultures containing Lactobacilli and/or Bifi dobacteria can be tolerated by lactoseintolerant individuals, possibly because these fermented products contain the microbial $\beta$ galactosidase which functions in the small intestine to support lactose hydrolysis [70]. Additionally, it has been demonstrated that in mice Streptococcus thermophilus or Lactobacillus casei subsp defensis are able to hydrolyze lactate during transit through the gut [71].

\section{APPLICATIONS OF PROBIOTICS IN VARIOUS DISEASES:}

\section{Crohn's disease and ulcerative colitis:}

Crohn's disease (CD) and ulcerative colitis (UC) are the chronic diseases of GIT with more or less common symptoms. Both are collectively called inflammatory bowel disease (IBD).Crohn's disease is associated with diarrhea, weight loss and abdominal pain while Ulcerative colitis has the symptoms of diarrhea and bleeding Clinical placebo controlled studies shows that Probiotics cause improvement in the condition of IBD[72].

\section{Inflammatory bowel disease:}

Probiotics are used in the treatment of inflammatory bowel disease considering that bacteria are involved in the etiology of the disease. Different studies show beneficial effect of probiotic in the treatment of inflammatory bowel disease in animal models [73].

\section{Effects on diarrheal diseases:}

The World Health Organization (WHO) estimates 8.1 million deaths occur yearly in children $(<5$ years of age) with diarrhea accounting for $14 \%$ of those deaths [74]. Diarrhea elicits serious long-term effects with multiple episodes and persistent diarrhea affecting growth, nutrition, and cognition [75]. Rotavirus is the most common cause of diarrhea in children [76]. The beneficial effects of probiotics on preventing rotavirus-caused diarrhea have been studied with a standard infant formula which is supplemented with Bifidobacterium bifidum $(1.9 \times 108 \mathrm{CFU} / \mathrm{g})$ and Streptococcus thermophilus $(1.4 \times 107 \mathrm{CFU} / \mathrm{g})$ for 14 days. The results demonstrated significantly lower numbers of children experiencing diarrhea who received the supplemented formula compared to unsupplemented control groups [77]. The European Society for Pediatric Gastroenterology, Hepatology and Nutrition (ESPGHAN) and the European Society for Pediatric Infectious Diseases recommend that only probiotic strains with proven clinical efficacy and in appropriate dosages be used as an adjunct to rehydration therapy for the management of children with acute diarrhea [78].

\section{Antibiotic associated diarrhea:}

Antibiotics disturb the gastrointestinal flora and cause diarrhea as a side effect $[79,80]$. The incidence of antibiotic-associated diarrhea (AAD) ranges between $5 \%$ and $30 \%$. The risk is greatest with amino penicillin therapies (Ampicillin or Amoxicillin), amino penicillin combined with clavulanic acid, cephalosporins, and clindamycin [81]. Probiotics given in conjunction with antibiotics have been extensively studied for the prevention of AAD in both adults and children. The major changes in the microbiota of the gut with antibiotics are 
Yasaman Pakdaman, Journal of Biomedical and Pharmaceutical Research

decrease in total number and species diversity of Bacteroides and Bifiobacteria associated with decreased amylolytic activity with increase in facultative anaerobes such as Fusobacteria, Clostridia, and Eubacteria species [82]. Decreased short chain fatty acid production and increased proteolytic activity was also noted in elderly patients treated with antibiotics [83]. Ingestion of certain probiotic strains, primarily Lactobacilli either alone or in combination with other genera, before and during antibiotic treatment reduces the frequency, duration and severity of antibiotic induced diarrhea [84].

\section{Helicobacter pylori Infections:}

Helicobacter pylori, a small curved to spiral rod shaped bacterium, is strongly associated with duodenal peptic ulceration and it is the main etiologic agent of chronic gastritis and gastric cancer and other gastric malignancies. Today the therapy to eradicate this bacterium is based on a combination of antibiotics and proton pump inhibitors. Probiotics seem to have a direct antimicrobial effect, as shown through in vitro studies, through competition with H. pylori, inhibition of adherence and production of metabolites and antimicrobial molecules. In a randomized, double blind, placebo-controlled trial, 60 participants were treated with triple antibiotic therapy on days 17 and Lactobacillus GG on days 1-14 [85].

Results of clinical trials indicate that probiotics generally do not eradicate $H$. pylori, but decrease the density of colonization, thereby maintaining lower levels of this pathogen in the stomach; in association with antibiotic treatments, some probiotics increased eradication rates and/or decreased adverse effects due to the antibiotics. Many studies show a moderate higher eradication rate ( $10 \%)$ of $H$. pylori when probiotics are added to the antibiotics and proton pump inhibitor [86].Although L. rhamnosus GG appears not to improve eradication,[87]most probiotic bacteria and yeasts reduce the adverse effects of standard $H$. pylori eradication regimens.[88,89]. Probiotics supplementation in triple therapy for $H$. pylori infection may have beneficial effects on eradication and therapy-related side effects, particularly diarrhea, in children [90]. Lactobacillus salivarius capable of producing high amounts of lactic acid, which can inhibit the growth of H. pylori in vitro [91].

\section{Diabetes Mellitus:}

Diabetes management includes a large number of medications but none of them could be helpful in complete cure of disorder. Many researches are being carried out at bimolecular and pharmacological level. One of the efforts to cure this disorder is to use symbiotic (probiotic and prebiotics). Recent researches show that there is a connection between bacterial population in gut and metabolic disease in human (especially diabetes). Recent studies based on large-scale 16S rRNA gene sequencing, quantitative real time PCR (qPCR) and fluorescent in situ hybridization (FISH), have shown that there is a connection between the composition of the intestinal microbiota and metabolic diseases like obesity and diabetes [92]. Low-fat (2.5\%) dahi containing probiotics Lactobacillus acidophilus and Lactobacillus casei was tested in rats against high fructose-induced type-2 diabetes. Both these bacteria proved beneficial effect in lowering blood glucose by decreasing insulin resistance [93]. It is also suggested that the use of probiotics can decrease the insulin resistance and can also lower the incident of hypertensive conditions that are closely related to diabetes. It has also been found that Bifidobacterium spp delivers pharmaco nutritional support in treating insulin resistance [94].

\section{Hypertension and Hypercholesteramia:}

Most important causes of hypertension are lipid abnormality, hypercholesterolemia and obesity [95]. New researches have shown that 
Yasaman Pakdaman, Journal of Biomedical and Pharmaceutical Research

not only the Lactobacilli exhibit hypocholesterolemic effects, but Bifidobacteria could also cause a significant reduction in serum cholesterol when cholesterol is elevated. As we know that most of the cholesterol is synthesized and absorbed in intestine, therefore intestinal micro flora has shown to effect cholesterol level in blood. Studies have shown that probiotics have been proved beneficial in lowering hypertension by decreasing blood cholesterol level and increasing resistance of LDL to oxidation [96].

A randomized, crossover, and placebo controlled design trial was performed to test the hypocholesterolemic effect of yoghurt containing $L$. acidophilus and $B$. longum by administering $300 \mathrm{~g} /$ day yogut for 21 weeks. The result of the study showed that HDL increased significantly [97]. Another placebocontrolled experiment was performed to study the effects of a probiotic containing food on blood cholesterol levels in 20 young Swiss mice. The results showed that the food sample of $L$. casei and Saccharomyces boulardii cause $19 \%$ decrease in total serum cholesterol, while LDL cholesterol levels was decreased by $37 \%$ after the 42 day feeding trial [98]. Most important biochemical factor which regulate blood pressure is rennin-angiotensin system (RAS) [99]. Angiotensin converting enzyme (ACE) regulates this pathway. There are some probiotics which upon fermentation produces proteinases capable of producing ACE inhibitory peptides. And thus regulate blood pressure [100].

\section{Upper respiratory tract infection:}

Upper respiratory tract infection includes laryngitis, tracheal inflammation and common cold and these are associated with symptoms like fever, headache, and pain and cough [101]. Most of the upper respiratory tract infections (URTs) are caused by viruses and these resolve in 3 to 7 days. Fermented food containing probiotics like Lactic acid bacteria and bifidobacteria are found to reduce the episode of URTs. Probiotics are also found to decrease the risk and incidence of respiratory tract infection (RTIs) in the children having age of 3 5 years [102].

\section{Atopic diseases:}

Atopic dermatitis is the first symptom of atopic disease and it is a chronic skin condition associated with inflammation and pruritis, eczematous papules, itch and plaques. It is one of the most prevalent skin diseases [103]. Atopic dermatitis tends to run in family, children are high risk of developing atopic disease whose mother is atopic. It is found that probiotics play a major role in reducing occurrence of atopic diseases. The risk of occurrence of eczema during first 2 years of infant life was reduced significantly in those whose mother received probiotics as compared to those whose mother takes placebo [104].

\section{Liver diseases:}

The liver and gut has an important relation in a sense that the blood is carried form gut to the portal system. Liver functions are stimulated by intestinal blood content. Similarly bile secretion produced by liver affects gut performance. It is found that any change in the normal composition of gut micro flora alter liver function and can lead to initiation and progression of liver diseases. Many complications (Hepatic encephalopathy, cirrhosis, spontaneous bacterial peritonitis) are associated with overgrowth of harmful bacteria, changed intestinal permeability and improper immune function. Probiotics are useful in the treatment of chronic liver diseases as they block entry of microorganisms to blood flow and ultimately to liver by increasing the strength of intestinal barrier [105]. Another mechanism involves the regulation of gut micro flora and regulation of immune functions [106,72].

\section{Acute Pancreatitis:}


Probiotics have been shown to be effective in preventing complications in experimental acute pancreatitis by reducing bacterial translocation [107]. A clinical trial conducted on patients with acute pancreatitis with $L$. plantarum 299 dose of $1 \times 10^{9}$ along with oat fiber significantly reduced infected pancreatic necrosis and the number of surgical interventions [108]. Subsequently, several studies reported similarly positive effects of probiotics with or without prebiotics [109, 110].

\section{Colon cancer:}

In laboratory experimentation, some stains of LAB (Lactobacillus delbrueckii subsp. bulgaricus) have shown anti-mutagenic effects because they have ability to bind with heterocyclic amines which are carcinogenic [111]. Animal studies proved beneficial effects of $L A B$ against colon cancer of rodents. Human trials also suggest that some types of $L A B$ are anti-carcinogenic due to ability to decrease the activity of enzyme called $\beta$ glucuronidase (which can generate cancer producing substances in the digestive system). The incidence of colon cancer in people consuming dairy product has been low compared to others during population studies [112].

\section{Clostridium difficile infections:}

Clostridium difficile is a spore-forming, anaerobic, Gram-positive bacterium that causes gastrointestinal infection with diarrhea and colitis. An enzyme weigh $54 \mathrm{kDa}$ serine protease produced by $S$. boulardii which directly degrades $C$. difficile toxin $A$ and $B$ and also produces a protease capable of degrading the colonic receptor site for $C$. difficile. S. boulardii may cause an increase in anti-toxin secretory IgA levels in the intestine [113,114]. Several randomized-controlled trials used Lactobacillus spp, Saccharomyces boulardii or a combination with $C$. difficile toxin acquisition and/or CDI as a primary or secondary outcome [115-122]. The trials had a small number of cases and short follow-up, the longest being 7 weeks by McFarland et al. [115]. Statistically significant decrease in CDI with use of a combination probiotic milkshake. No patients in the probiotic group acquired CDI, whereas 9 out of $53(17 \%)$ in the placebo group developed CDI $(P=0.001)$ (122).

\section{Conclusion:}

Probiotics seem to have promising role in shortening duration of infections or decreasing susceptibility to the pathogens. Incorporation of probiotics in nutrition as a means of derivation of health benefits. The best documented effects include bowel disorders such as lactose intolerance, antibioticassociated diarrhea and infectious diarrhea, emerging evidence accumulates concerning their potential role in various other conditions. In the same time as relevant consumer awareness grows, such products are becoming increasingly popular and tend to represent one of the largest functional food markets. Dairy products, particularly yoghurt, continue to be the most important vehicles for delivery of probiotic bacteria to the consumer with the nondairy sector continuously evolving as well, as a result of food technology advances and the growing demand. There are evidences from well-conducted clinical trials of beneficial health effects from probiotics in a range of clinical conditions. from the ongoing research, more of promising potential health effects of probiotics are being observed, more standardized and verifiable clinical studies are needed to demonstrate the safety, efficacy, and limitations of a putative probiotic, to determine effects on the immune system in healthy and diseased individuals and effects of long-term consumption, and to resolve whether it is superior to existing therapies. Also, the prospect of GM probiotics targeted for clinical conditions demands a rigorous safety strategy to prevent spread into the environment and dissemination of the genetic modification. 
Yasaman Pakdaman, Journal of Biomedical and Pharmaceutical Research

\section{Bibliography:}

1. Qadir MI, Malik SA, Naveed AK and Ahmad I (2006) Plasma lipid profile in sarcoma patients. Pak. J. Pharm.Sci., 19: 155-158.

2. Qadir MI, Naveed AK, Ahmad I, Malik SA (2007) Plasma lipid profile in childhood non-Hodgkin lymphoma patients. Pak. Paed. J., 31: 167-70.

3. Qadir MI, Malik SA (2008) Plasma lipid profile in gynecologic cancers. Europ. J. Gyne. Oncol., 29:158-161.

4. Khalid SH, Qadir MI, Massud A, Ali M and Rasool $\mathrm{MH}$ (2009). Effect of degree of cross-linking on swelling and drug release behaviour of poly (methyl methacrylate-co-itaconic acid) [P(MMA/IA $)]$ hydrogels for site specific drug delivery. J. Drug. Delvr. Sci.Tech., 19(6): 413-418.

5. Hussain A, Khalid SH, Qadir MI, Massud A, Ali M, Khan IU, Saleem M, Iqbal MS, Asghar S and Gul H (2011). Water uptake and drug release behaviour of methyl methacrylate-co-itaconic acid (P/MMA/IA) Hydrogels Cross-linked with methylene bis-acrylamide. J. Drug.Delvr. Sci. Tech., 21(3): 249-255.

6. Naz S, Qadir MI, Ali M and Janbaz KH (2012) Nanotechnology for imaging and drug delivery in cancer. J. Chem. Soc. Pak., 34(1): 107-111.

7. Ehsan O, Qadir MI, Malik SA, Abbassi WS and Ahmad B (2012) Efficacy of nanogold-insulin as a hypoglycaemic agent. J. Chem. Soc. Pak., 34(2): 365370.

8. Qadir MI, Malik SA (2010) HIV fusion inhibitors. Rev.Med. Virol., 20: 23-33.

9. Qadir MI (2011) Qadirvirtide. Pak. J. Pharm. Sci., 24(4):593-595.

10. Qadir MI, Malik SA (2011) Genetic variation in the $H R$ region of the env Gene of HIV: A perspective for resistance to HIV fusion inhibitors. AIDS Res. Hum. Retrovir., 27: 57-63.
11. Masood MI, Qadir MI, Shirazi JH and Khan IU (2011). Beneficial effects of lactic acid bacteria on human beings. Critical Rev. Micro., 37(1): 91-98.

12. Javed F, Qadir MI, Janbaz KH and Ali M (2011). Novel drugs from marine microorganisms. Critical Rev.Micro., 37(3): 245-249.

13. Qadir MI (2009) Medicinal and cosmetological importance of Aloe vera. Int. J. Nat. Ther., 2: 21-26.

14. Qadir MI (2010) Medicinal values of ginger. Int. J. Nat.Ther., 3: 19-22.

15. Ahmad M, Mahmood Q, Gulzar K, Akhtar MS, Saleem M and Qadir MI (2012). Antihyperlipidaemic and hepatoprotective activity of Dodonaea viscosa leaves extracts in alloxaninduced diabetic rabbits (Oryctolagus cuniculus). Pak. Vet. J., 32(1): 50-54.

16. Ali $M$, Qadir $M I$, Saleem $M$, Janbaz KH, Gul H, Hussain L, Ahmad B (2013) Hepatoprotective potential of Convolvulus arvensis against paracetamol-induced hepatotoxicity. Bangladesh J. Pharmacol. , 8: 300-304.

17. Qadir MI, Nisa TU and Malik SA (2009). Effect of Eugenia jambolana leaves extracts on blood glucose levels of experimental diabetic rabbits. Pharmacology online, 3: 829-835.

18. Nisa TU, Qadir MI and Malik SA (2010) Anti-diabetic activity of inorganic metals Eugenia jambolana Lam. (Myrtaceae) flowers. Pharmacologyonline, 2: 979-985.

19. Asif MA and Qadir MI (2011). Molecular approaches for development of malarial vaccines. Rev. Pharmacol., 4:276-278.

20. Janbaz $\mathrm{KH}$, Qadir MI, Jan A, Gilani $\mathrm{AH}$ (2013a) Antidiarrheal activity of methanolic extract of Tephrosia purpurea. Acta Pol. Pharm., 79: 345347. 
Yasaman Pakdaman, Journal of Biomedical and Pharmaceutical Research

21. de Vrese $M$, Stegelmann $A$, Richter $B$, Fenselau S, Laue C, et al. (2001) Probiotics--compensation for lactase insufficiency. Am J Clin Nutr 73: 421S429S.

22. Zhong $\mathrm{Y}$, Priebe MG, Vonk RJ, Huang $\mathrm{CY}$, Antoine JM, et al. (2004) The role of colonic microbiota in lactose intolerance. Dig Dis Sci 49: 78-83.

23. Amin N, Qadir MI, Khan TJ, Abbas G, Ahmad B, Janbaz KH and Ali M (2012). Antibacterial activity of Vacuum liquid chromatography (VLC) isolated fractions of chloroform extracts of seeds of Achyranthes aspera. J.Chem. Soc. Pak., 34(3): 589-592.

24. Janbaz $\mathrm{KH}$, Jan $\mathrm{A}$, Qadir $\mathrm{MI}$, Gilani $\mathrm{AH}$ (2013b) Spasmolytic, bronchodilator and vasorelaxant activity of methanolic extract of Tephrosia purpurea. Acta Pol. Pharm., 79: 261-269.

25. Janbaz KH, Nizsar $U$, Ashraf $M$ and Qadir MI (2012) Spasmolytic, bronchodilator and antioxidant activities of Erythrina superosa Roxb. Acta Pol. Pharm., 69(6):1111-1117.

26. Scheinbach S (1998) Probiotics: functionality and commercial status. Biotechnol Adv 16: 581-608.

27. Antoine JM (2010) Probiotics: beneficial factors of the defence system. Proc Nutr Soc 69: 429-433.

28. Food and Agriculture Organization of the United Nations and World Health Organization. 2001, posting date. Regulatory and clinical aspects of dairy probiotics. Food and Agriculture Organization of the United Nations and World Health Organization Expert Consultation Report. Food and Agriculture Organization of the United Nations and World Health Organization Working Group Report. (Online.)

29. McFarland, L. V., and G. W. Elmer. 1995. Biotherapeutic agents: past, present and future. Microecol. Ther. 23:46-73.

30. Forestier C, De Champs C, Vatoux C \& Joly B (2001) Probiotic activities of Lactobacillus casei rhamnosus: in-vitro adherence to intestinal cells and antimicrobial properties.Res Microbiol 152: 167-173.

31. Salminen SJ, Gueimonde $M$ \& Isolauri $E$ (2005) Probiotics that modify disease risk. J Nutr 135: 1294-1298.

32. Kumar M, Behare PV, Mohania D, Arora S, Kaur A \& Nagpal R (2009a) Healthpromoting probiotic functional foods: potential and prospects. Agro Food Ind Hi Tech 20: 29-33.

33. Kailasapathy K \& Chin J (2000) Survival and therapeutic potential of probiotic organisms with reference to Lactobacillus acidophilus and Bifidobacterium spp. Immunol Cell Biol 78: 80-88.

34. Ohland CL, Macnaughton WK (2010) Probiotic bacteria and intestinal epithelial barrier function. Am J Physiol Gastrointest Liver Physiol 298: G807819.

35. Yan F, Polk DB (2006) Probiotics as functional food in the treatment of diarrhea. Curr Opin Clin Nutr Metab Care 9: 717-721.

36. Mack DR, Ahrne S, Hyde L, Wei S, Hollingsworth MA (2003) Extracellular MUC3 mucin secretion follows adherence of Lactobacillus strains to intestinal epithelial cells in vitro. Gut 52: 827-833.

37. Mattar AF, Teitelbaum DH, Drongowski RA, Yongyi F, Harmon CM, et al. (2002) Probiotics up-regulate MUC-2 mucin gene expression in a Caco-2 cell-culture model. PediatrSurgInt 18: 586-590.

38. Gaudier E, Michel C, Segain JP, Cherbut C) Hoebler C (2005) The VSL\# 3 probiotic mixture modifies microflora but does not heal chronic dextran- 
Yasaman Pakdaman, Journal of Biomedical and Pharmaceutical Research

sodium sulfate-induced colitis or reinforce the mucus barrier in mice. J Nutr 135: 2753- 2761.

39. Caballero-Franco C, Keller K, De Simone C, Chadee K (2007) The VSL\#3 probiotic formula induces mucin gene expression and secretion in colonic epithelial cells. Am J Physiol Gastrointest Liver Physiol 292: G315-322.

40. Kelsall BL (2008) Innate and adaptive mechanisms to control [corrected] pathological intestinal inflammation. J Pathol 214: 242-259.

41. Möndel $M$, Schroeder BO, Zimmermann K, Huber H, Nuding S, et al. (2009) Probiotic E. coli treatment mediates antimicrobial human beta-defensin synthesis and fecal excretion in humans. Mucosal Immunol 2: 166-172.

42. Schlee $M$, Harder J, Köten $B$, Stange EF, Wehkamp J, et al. (2008) Probiotic lactobacilli and VSL\#3 induce enterocyte beta-defensin 2. ClinExplmmunol 151: 528-535.

43. Roberfroid MB, Bornet F, Bouley C \& Cummings $\mathrm{JH}(1995)$ Colonic microflora: nutrition and health: summary and conclusions of an International Life Sciences Institute (Europe) workshop held in Barcelona, Spain. Nutr Rev 53: 127-130.)

44. Penner $\mathrm{R}$, Fedorak RN, Madsen $\mathrm{KL}$ (2005) Probiotics and nutraceuticals: non-medicinal treatments of gastrointestinal diseases. CurrOpinPharmacol 5: 596- 603.

45. Alakomi HL, Skyttä $E$, Saarela $M$, Mattila-Sandholm T, Latva-Kala K, et al. (2000) Lactic acid permeabilizes gramnegative bacteria by disrupting the outer membrane. Appl Environ Microbiol 66: 2001-2005.

46. Liévin-Le Moal V, Servin AL (2006) The front line of enteric host defense against unwelcome intrusion of harmful microorganisms: mucins, antimicrobial peptides, and microbiota. Clin Microbiol Rev 19: 315-337.

47. Duquesne S, Petit V, Peduzzi J, Rebuffat $S$ (2007) Structural and functional diversity of microcins, gene-encoded antibacterial peptides from enterobacteria.

MolMicrobiolBiotechnol 13: 200-209.

48. Johnson-Henry KC, Hagen KE, Gordonpour M, Tompkins TA, Sherman PM (2007) Surface-layer protein extracts from Lactobacillus helveticus inhibit enterohaemorrhagic Escherichia coli 0157:H7 adhesion to epithelial cells. Cell Microbiol 9: 356-367.

49. Wu X, Vallance BA, Boyer L, Bergstrom KS, Walker J, et al. (2008) Saccharomyces boulardii ameliorates Citrobacter rodentium-induced colitis through actions on bacterial virulence factors. Am J Physiol Gastrointest Liver Physiol 294: G295-306.

50. Galdeano CM, Perdigón G (2006) The probiotic bacterium Lactobacillus casei induces activation of the gut mucosal immune system through innate immunity. Clin Vaccine Immunol 13: 219-226.

51. Ogawa $M$, Shimizu K, Nomoto $K$, Takahashi M, Watanuki M, et al. (2001) Protective effect of Lactobacillus casei strain Shirota on Shiga toxin-producing Escherichia coli 0157:H7 infection in infant rabbits. Infect Immun 69: 11011108.

52. Tien MT, Girardin SE, Regnault $B$, Le Bourhis L, Dillies MA, et al. (2006) Antiinflammatory effect of Lactobacillus caseion Shigella-infected human intestinal epithelial cells. J Immunol 176: 1228-1237.

53. Miller MB, Bassler BL (2001) Quorum sensing in bacteria. Annu Rev Microbiol 55: 165-199. 
Yasaman Pakdaman, Journal of Biomedical and Pharmaceutical Research

54. Kendall MM, Sperandio V (2007)

62. Pereira DI, Gibson GR (2002) Quorum sensing by enteric pathogens. CurrOpinGastroenterol 23: 10-15.

55. Medellin-Peña MJ, Wang $\mathrm{H}$, Johnson $\mathrm{R}$, Anand S, Griffiths MW (2007) Probiotics affect virulence-related gene expression in Escherichia coli 0157:H7. Appl Environ Microbiol 73: 4259-4267.

56. F. Guarner, A. G. Khan, J. Garisch, R. Eliakim, A. Gangl, A. Thomson, et al. 2009 World Gastroenterology Organisation Practice Guideline: Probiotics and prebiotics. Arab j. gastroenterol. 103342 .

57. Roberfroid M, Gibson GR, Hoyles L, McCartney $A L$, Rastall R, Rowland I, Wolvers D, Watzl B, Szajewska H, Stahl B, Guarner F, Respondek F, Whelan K, Coxam V, Davicco M-J, Léotoing $L$, Wittrant Y, Delzenne NM, Cani PD, Neyrinck AM and Meheust A (2010). Prebiotic effects: Metabolic and health benefits. Br. J.Nutr., 104: 1-63.

58. Conly JM, Stein K, Worobetz L \& Rutledge-Harding S (1994) The contribution of vitamin $\mathrm{K} 2$ (metaquinones) produced by the intestinal microflora to human nutritional requirements for vitamin $\mathrm{K}$. Am J Gastroenterol 89: 915-923.

59. Younes $\mathrm{H}$, Coudray $\mathrm{C}$, Bellanger J et al. (2001) Effects of two fermentable carbohydrates (inulin and resistant starch) and their combination on calcium and magnesium balance in rats. Br J Nutr 86: 479-485.

60. Levy, J., 2000. The effects of antibiotic use on gastrointestinal function. Am. J. Gastroenterol. 95, S8-S10.

61. Lambert JM, Bongers RS, de Vos WM, Kleerebezem M (2008) Functional analysis of four bile salt hydrolase and penicillin acylase family members in Lactobacillus plantarum WCFS1. Appl Environ Microbiol 74: 4719-4726.

Cholesterol assimilation by lactic acid bacteria and Bifidobacteria isolated from the human gut. Appl Environ Microbiol 68: 4689-4693.

63. Liong MT, Shah NP (2006) Effects of a Lactobacillus casei synbiotic on serum lipoprotein, intestinal microflora, and organic acids in rats. J Dairy Sci 89: 1390-1399.

64. Liong MT, Shah NP (2005) Acid and bile tolerance and cholesterol removal ability of Lactobacilli strains. J Dairy Sci 88: 55-66.

65. Lye HS, Rusul G, Liong MT (2010) Removal of cholesterol by Lactobacilli via incorporation and conversion to coprostanoL. J Dairy Sci 93: 1383-1392.

66. Lye HS, Rusul G, Liong MT (2010) Mechanisms of cholesterol removal by Lactobacilli under conditions that mimic the human gastrointestinal tract. Int Dairy J 20: 169-175.

67. De Preter V, Vanhoutte T, Huys G, Swings J, De Vuyst L, et al. (2007) Effects of Lactobacillus caseiShirota, Bifidobacteriumbreve, and oligofructose-enriched inulin on colonic nitrogen-protein metabolism in healthy humans. Am J Physiol Gastrointest Liver Physiol 292: 358-368.

68. Lin $Y$, Meijer GW, Vermeer MA, Trautwein EA (2004) Soy protein enhances the cholesterol-lowering effect of plant sterol esters in cholesterol-fed hamsters. J Nutr 134: 143-148.

69. Suarez FL, Savaiano DA (1997) Diet, genetics, and lactose intolerance. Food Tech 51: 74-76.

70. de Vrese $M$, Sieber R, Stransky $M$ (1999) Lactose malabsorption and eating yogurt. Schweiz Med Wochenschr 129: 253-254.

71. Oozeer R, Goupil-Feuillerat N, Alpert $C A$, van de Guchte $M$, Anba J, et al. 
Yasaman Pakdaman, Journal of Biomedical and Pharmaceutical Research

(2002) Lactobacillus casei is able to survive and initiate protein synthesis during its transit in the digestive tract of human flora-associated mice. Appl Environ Microbiol 68: 3570-3574.

72. Jonkers D and Stockbrügger R. (2007), Probiotics in gastrointestinal and liver diseases. Aliment Pharmacol. Ther.,26: 133-148.

73. Gionchetti $P$, Amadini C, Rizzello $F$, Venturi A, Palmonari V, Morselli C, Romagnoli R and Campieri M (2002). Probiotics Role in inflammatory bowel disease. Digest. Liver Dis., 34: 58-62.

74. Black RE, Cousens S, Johnson HL, Lawn JE, Rudan I, et al. (2010) Global, regional, and national causes of child mortality in 2008: a systematic analysis. Lancet 375: 1969-1987.

75. Guerrant RL, Oriá RB, Moore SR, Oriá MO, Lima AA (2008) Malnutrition as an enteric infectious disease with longterm effects on child development. Nutr Rev 66: 487-505.

76. Claeson M, Merson MH (1990) Global progress in the control of diarrheal diseases. Pediatr Infect Dis J 9: 345-355.

77. Saavedra JM, Bauman NA, Oung I, Perman JA, Yolken RH (1994) Feeding of Bifidobacterium bifidum and Streptococcus thermophilus to infants in hospital for prevention of diarrhoea and shedding of rotavirus. Lancet 344 : 1046-1049.

78. Guarino A, Albano F, Ashkenazi S (2008) European society for paediatric gastroenterology, hepatology, and nutrition/European society for paediatric infectious diseases evidencebased guidelines for the management of acute gastroenteritis in children in Europe. J Paediatr Gastroenterol Nutr 46: S81-S122.

79. McFarland LV (1998) Epidemiology, risk factors and treatments for antibiotic- associated diarrhea. Dig Dis 16: 292307.

80. Barbut F, Meynard JL (2002) Managing antibiotic associated diarrhoea. BMJ 324: 1345-1346.

81. Bartlett JG (1996) Management of Clostridium difficile infection and other antibiotic-associated diarrhoeas. Eur J GastroenterolHepatol 8: 1054-1061.

82. Mueller S, Saunier K, Hanisch C, Norin $E$, Alm L, et al. (2006) Differences in fecal microbiota in different European study populations in relation to age, gender, and country: a cross-sectional study. Appl Environ Microbiol 72: 1027 1033.

83. Guigoz Y, Doré J, Schiffrin EJ (2008) The inflammatory status of old age can be nurtured from the intestinal environment. CurrOpinClinNutrMetab Care 11: 13-20.

84. Hempel S, Newberry SJ, Maher AR, Wang Z, Miles JN, et al. (2012) Probiotics for the prevention and treatment of antibiotic-associated diarrhea: a systematic review and meta-analysis. JAMA 307: 1959-1969.

85. Armuzzi A, Cremonini F, Bartolozzi F, Canducci F, Candelli M, et al. (2001) The effect of oral administration of Lactobacillus $G G$ on antibioticassociated gastrointestinal side-effects during Helicobacter pylori eradication therapy. Aliment Pharmacol Ther 15: 163-169.

86. Szajewska $H$, Horvath A, Piwowarczyk A. Meta-analysis: the effects of Saccharomyces boulardii supplementation onHelicobacter pylori eradication rates and side effects during treatment. Aliment Pharmacol Ther. 2010;32:1069---79.

87. Szajewska H, Albrecht P, TopczewskaCabanek A. Randomized, double-blind, placebo-controlled trial: effect of Lactobacillus GG supplementation on 
Yasaman Pakdaman, Journal of Biomedical and Pharmaceutical Research

Helicobacter pylori eradication rates and side effects during treatment in children. J Pediatr Gastroenterol Nutr. 2009;48:431---6.

88. Malfertheiner $P$, Selgrad $M$, Bornschein J. Helicobacter pylori: clinical management. CurrOpinGastroenterol. 2012;28:608---14.

89. Wilhelm SM, Johnson JL, Kale-Pradhan PB. Treating bugs with bugs: the role of probiotics as adjunctive therapy for Helicobacter pylori. Ann Pharmacother. 2011;45:960---6.

90. Li S, Huang XL, Sui JZ, Chen SY, Xie YT, Deng $Y$, et al. Metaanalysis of randomized controlled trials on the efficacy of probiotics in Helicobacter pylori eradication therapy in children. Eur J Pediatr. 2014;173:153---61.

91. Aiba, Y., Suzuki, N., Kabir, A.M., Takagi, A., Koga, Y., 1998. Lactic acid-mediated suppression of Helicobacter pylori by the oral administration of Lactobacillus salivarius as a Probiotic in a gnotobiotic murine model. Am. J. Gastroenterol. 93, 2097-2101.

92. Larsen $\mathrm{N}$, Vogensen FK, van den Berg FW, Nielsen DS, Andreasen AS, Pedersen BK, Al-Soud WA, Sørensen SJ, Hansen LH and Jakobsen M (2010). Gut microbiota in human adults with type 2 diabetes differs from non-diabetic adults. PLoS ONE, 5: e9085.

93. Yadav H, Jain S and Sinha PR (2007). Antidiabetic effect of probiotic dahi containing Lactobacillus acidophilus and Lactobacillus casei in high fructose fed rats. Nutr, 23: 62-68

94. Cani PD and Delzenne NM (2011). The gut microbiome as therapeutic target. Pharmacol. Ther.,130: 202-212.

95. Yekeen LA, Sanusi RA and Ketiku AO (2003). Prevalence of obesity and high level of cholesterol in hypertension: Analysis of data from the university college hospital, Ibadan. Afr. J. Biomed. Res., 6: 129-132.

96. Goel A.K, Dilbaghi N, Kambojm DV and Singh L (2006) Probiotics: Microbial therapy for health modulation. Defence. Sci. J., 56: 513-529.

97. Kieling G., Schneider J and Jahreis G (2002). Long-term consumption of fermented dairy products over 6 months increases HDL cholesterol. Eur. J. Clin. Nutr, 56: 843-849.

98. Sindhu SC and Khetarpaul N (2003). Effect of feeding probiotic fermented indigenous food mixture on serum cholesterol levels in mice. Nutr. Res., 23: 1071-1080.

99. FitzGerald RJ, Murray BA and Walsh DJ (2004), Hypotensive peptides from milk proteins. J. Nutr., 134:980-988.

100. Yamamoto $\mathrm{N}$ and Takano T (1999). Antihypertensive peptides derived from milk proteins. Nahrung, 43: 159-164.

101. Hao Q, Lu Z, Dong BR, Huang CQ and Wu T (2011). Probiotics for preventing acute upper respiratory tract infections, Cochrane Database of Systematic Reviews, Issue 9. Art. No: CD006895. DOI:

10.1002/14651858.CD006895.pub2.

102. Ouwehand A, Leyer $G$ and Carcano D (2008). Probiotics reduce incidence and duration of respiratory tracts infection symptoms in 3- to 5-year-old children. Pediatrics, 121: 115.

103. Simpson EL (2010). Atopic dermatitis: A review of topical treatment options. Curr. Med. Res. Opin., 26:633-640

104. Rautava $S$, Kalliomäki $M$ and Isolauri $E$ (2002). Probiotics during pregnancy and breastfeeding might confer immunomodulatory protection against atopic disease in the infant. J. Allergy Clin. Immunol.,109:191-121.

105. Cesaroa C, Tisoa A, Pretea AD, Cariellob R, Tuccilloa C, Cotticellia G, Blancoa CDV and Loguercioa C (2011). Gut 
Yasaman Pakdaman, Journal of Biomedical and Pharmaceutical Research

microbiota and probiotics in chronic liver diseases. Digest. Liver Dis., 43: 431-438.

106. Sheth AA and Garcia-Tsao G (2008), Probiotics and liver disease. J. Clin Gastroenterol, 42: 80-84.

107. Akyol S, Mas MR, Comert B, Ateskan U, Yasar M, et al. (2003) The effect of antibiotic and probiotic combination therapy on secondary pancreatic infections and oxidative stress parameters in experimental acute necrotizing pancreatitis. Pancreas 26: 363-367.

108. Oláh A, Belágyi T, Issekutz A, Gamal ME, Bengmark S (2002) Randomized clinical trial of specific lactobacillus and fibre supplement to early enteral nutrition in patients with acute pancreatitis. $\mathrm{Br} \mathrm{J}$ Surg 89: 1103-1107.

109. Qin HL, Zheng JJ, Tong DN, Chen WX, Fan XB, et al. (2008) Effect of Lactobacillus plantarum enteral feeding on the gut permeability and septic complications in the patients with acute pancreatitis. Eur J ClinNutr 62: 923930.

110. Oláh $A$, Belágyi $T$, Pótó $L$, Romics $L$ Jr, Bengmark S (2007) Synbiotic control of inflammation and infection in severe acute pancreatitis: a prospective, randomized, double blind study. Hepatogastroenterology 54: 590-594.

111. Wollowski I, Rechkemmer $G$ and PoolZobel BL (2001). Protective role of probiotics and prebiotics in colon cancer. Am. J. Clin. Nutr.,73: 451-455.

112. Brady $\amalg$, Gallaher DD and Busta FF (2000). The role of probiotic cultures in the prevention of colon cancer. J.Nutr.,130: 410-414.

113. Castagliuolo I, LaMont JT, Nikulasson ST, Pothoulakis C (1996) Saccharomyces boulardii protease inhibits Clostridium difficile toxin A effects in the rat ileum. Infect Immun 64: 5225-5232.
114. Qamar A, Aboudola S, Warny $M$, Michetti P, Pothoulakis C, et al. (2001) Saccharomyces boulardii stimulates intestinal immunoglobulin A immune response to Clostridium difficile toxin $A$ in mice. Infect Immun 69: 2762-2765.

115. McFarland LV, Surawicz CM, Greenberg RN, Elmer GW, Moyer KA, et al. (1995) Prevention of beta-lactam-associated diarrhea by Saccharomyces boulardii compared with placebo. Am J Gastroenterol 90: 439-448.

116. Plummer $S$, Weaver MA, Harris JC, Dee $P$, Hunter J (2004) Clostridium difficile pilot study: effects of probiotic supplementation on the incidence of $C$. difficile diarrhoea. Int Microbiol 7: 5962.

117. Thomas MR, Litin SC, Osmon DR, Corr $A P$, Weaver AL, et al. (2001) Lack of effect of Lactobacillus $G G$ on antibioticassociated diarrhea: a randomized, placebo-controlled trial. Mayo Clin Proc 76: 883-889.

118. Surawicz CM, Elmer GW, Speelman $P$, McFarland LV, Chinn J, et al. (1989) Prevention of antibiotic-associated diarrhea by Saccharomyces boulardii: a prospective study. Gastroenterology 96: 981-988.

119. Lewis SJ, Potts LF, Barry RE (1998) The lack of therapeutic effect of Saccharomyces boulardii in the prevention of antibiotic-related diarrhoea in elderly patients. J Infect 36: 171-174.

120. Kotowska M, Albrecht P, Szajewska H (2005) Saccharomyces boulardii in the prevention of antibiotic-associated diarrhoea in children: a randomized double-blind placebo-controlled trial. Aliment Pharmacol Ther 21: 583-590.

121. Can M, Besirbellioglu BA, Avci IY, Beker CM, Pahsa A (2006) Prophylactic Saccharomyces boulardii in the prevention of antibiotic-associated 
Yasaman Pakdaman, Journal of Biomedical and Pharmaceutical Research

diarrhea: a prospective study. Med SciMonit 12: PI19-22.

122. Hickson $M, D^{\prime}$ Souza $A L$, Muthu $N$, Rogers TR, Want S, et al. (2007) Use of probiotic Lactobacillus preparation to prevent diarrhoea associated with antibiotics: randomised double blind placebo controlled trial. BMJ 335: 80. 